\title{
Seasonal variations in larval biomass and biochemical composition of brown shrimp, Crangon crangon (Decapoda, Caridea), at hatching
}

\author{
Ángel Urzúa · Klaus Anger
}

Received: 26 April 2012/Revised: 13 July 2012/ Accepted: 17 July 2012/Published online: 31 July 2012

(C) Springer-Verlag and AWI 2012

\begin{abstract}
The "brown shrimp", Crangon crangon (Linnaeus 1758), is a benthic key species in the North Sea ecosystem, supporting an intense commercial fishery. Its reproductive pattern is characterized by a continuous spawning season from mid-winter to early autumn. During this extended period, C. crangon shows significant seasonal variations in egg size and embryonic biomass, which may influence larval quality at hatching. In the present study, we quantified seasonal changes in dry weight (W) and chemical composition (CHN, protein and lipid) of newly hatched larvae of $C$. crangon. Our data revealed significant variations, with maximum biomass values at the beginning of the hatching season (February-March), a decrease throughout spring (April-May) and a minimum in summer (June-September). While all absolute values of biomass and biochemical constituents per larva showed highly significant differences between months $(P<0.001)$, CHN, protein and lipid concentrations (expressed as percentage values of dry weight) showed only marginally significant differences $(P<0.05)$. According to generalized additive models (GAM), key variables of embryonic development exerted significant effects on larval condition at hatching: The larval carbon content (C) was positively correlated with embryonic carbon content shortly after egg-laying $\left(r^{2}=0.60 ; P<0.001\right)$ and negatively with the average incubation temperature during the period of embryonic
\end{abstract}

Communicated by H.-D. Franke.

Á. Urzúa $(\bowtie)$

Christian-Albrechts-Universität zu Kiel, Kiel, Germany

e-mail: Angel.Urzua@awi.de

Á. Urzúa $\cdot$ K. Anger

Biologische Anstalt Helgoland, Alfred-Wegener-Institut für

Polar und Meeresforschung, 27498 Helgoland, Germany development $\left(r^{2}=0.35 ; P<0.001\right)$. Additionally, water temperature $\left(r^{2}=0.57 ; P<0.001\right)$ and food availability (phytoplankton $\mathrm{C} ; r^{2}=0.39 ; P<0.001$ ) at the time of hatching were negatively correlated with larval $\mathrm{C}$ content at hatching. In conclusion, "winter larvae" hatching from larger "winter eggs" showed higher initial values of biomass compared to "summer larvae" originating from smaller "summer eggs". This indicates carry-over effects persisting from the embryonic to the larval phase. Since "winter larvae" are more likely exposed to poor nutritional conditions, intraspecific variability in larval biomass at hatching is interpreted as part of an adaptive reproductive strategy compensating for strong seasonality in plankton production and transitory periods of larval food limitation.

Keywords Crangon crangon - Eggs · Larvae .

Biochemical composition - Seasonal variations .

Carry-over effects · Southern North Sea · Food availability

\section{Introduction}

Marine organisms with a complex life cycle develop through a series of different ontogenetic stages including embryonic, larval, juvenile and adult phases, which are linked to each other (Giménez 2006; Podolsky and Moran 2006). In invertebrates and fish, variability in the density of adult populations has mainly been attributed to fluctuations in brood size and to variations in growth and mortality during earlier life-history stages (McCormick and Hoey 2004; Marshall and Keough 2006).

The environmental conditions experienced during the embryonic phase have been recognized as important factors influencing larval performance, and therefore, indirectly also later benthic life-history phases of marine invertebrates 
(Grosberg and Levitan 1992; Giménez 2010). In all pleocyemate decapod crustaceans, the eggs are carried under the abdomen of the females and thus experience the parental environmental conditions prevailing in the habitat. Newly laid eggs contain all the energy that is necessary for embryonic development (Jaeckle 1995), and therefore, the initial larval biomass depends on both these initial energy reserves and their subsequent utilization during embryogenesis (Anger 2001). Also, it is influenced by physico-chemical factors experienced during embryogenesis, for example, temperature (Wear 1974; Fischer et al. 2009), oxygen (Fernandez et al. 2006) and salinity (Giménez and Anger 2001), so that previous environmental conditions may also affect the larval capacity to face starvation during periods of planktonic food limitation (Paschke et al. 2004; Calado et al. 2007).

In the pelagic marine environment, crustacean larvae may seasonally be exposed to food limitation and temperature changes, and combined effects of both factors may influence their growth and development (Anger 2001). As an adaptation to seasonal variation in food availability, planktotrophic larvae may therefore seasonally vary in their energy content at hatching, showing enhanced endogenous reserves during periods of low plankton productivity (Anger 2001, 2006). In temperate and high-latitude marine invertebrates, this reproductive trait has been interpreted as an evolutionary adaptation to a mismatch between short seasonal periods of planktonic food availability and a prolonged larval development at low temperatures (e.g. Anger et al. 2003).

Environmental effects on sets of reproductive traits of organisms can have important consequences on populations. For a better understanding of the ecology of species with complex life cycles, we need to study how the various life-history phases are connected to each other. One important link is between the embryonic and the larval phase. In this context, the larval performance can be related to maternal input, conditions experienced during embryogenesis, and to environmental factors prevailing at hatching or thereafter (Giménez 2006). The combination of these pre- and post-hatching factors may explain larval survival and, consequently, affect also later phases of the life cycle (Roughgarden et al. 1988; Giménez 2010). Hence, the quality of early larval stages may be relevant not only for the settlement and recruitment success in the field (Pan et al. 2011), but also for aquaculture (Racotta et al. 2003) and fisheries management (Campos et al. 2009).

The subject of this study is the generally well studied and commercially important "brown shrimp", Crangon crangon. This species is very common and abundant in the shallow areas of the German Bight (Siegel et al. 2008), plays an important role in the energy transfer within marine food webs (Pihl and Rosenberg 1984; Campos et al. 2009) and sustains an important fishery with annual captures exceeding 35,000 tons (ICES 2010). The complex life cycle of $C$. crangon comprises a benthic juvenile-adult and a pelagic larval phase (Tiews 1970; Hufnagl and Temming 2011), which are tightly linked (Daewel et al. 2011; Viegas et al. 2012). It is thus necessary to also investigate traits of the early life-history phases, which may influence the population dynamics.

The reproductive pattern of $C$. crangon is characterized by continuous egg-laying from mid-winter throughout spring, summer and early autumn. During this extended period, this species shows significant seasonal variations in size and biomass of newly laid eggs (Boddeke 1982; Urzúa et al. 2012). However, the question remains, whether seasonal variations in egg biomass directly translate to variations in larval quality at hatching, as suggested by studies of larval tolerance of food limitation (Paschke et al. 2004). We therefore explored relationships between previously published data of biomass and chemical composition of eggs (Urzúa et al. 2012), water temperature during embryogenesis (Wiltshire et al. 2010) and larval biomass at hatching, which may indicate "latent" or "carry-over effects" between successive early life-history phases (Harrison et al. 2011).

\section{Materials and methods}

The methodology used in this study is described only briefly, as it is largely the same as explained in details in a recent paper dealing exclusively with the embryonic phase of C. crangon (Urzúa et al. 2012).

Sampling and maintenance of ovigerous females

Throughout most of the reproductive season of $C$. crangon in 2009 (January-September), shrimps were periodically sampled from a population living in the lower Elbe estuary $\left(54^{\circ} 03^{\prime}-54^{\circ} 04^{\prime} \mathrm{N} ; 8^{\circ} 18^{\prime}-8^{\circ} 24^{\prime} \mathrm{E}\right.$; ca $13 \mathrm{~m}$ depth) employing bottom trawls of research vessel "Uthörn". Adult individuals were transferred to the Helgoland Marine Biological Station. No samples were taken in October-December due to unavailability of ship time. In the laboratory, ovigerous females ( $n=32$; 48-54 mm total body length) were isolated and placed in aerated flow-through seawater aquaria with similar temperatures and salinities as in the field, until newly hatched larvae were found in sieves $(0.2 \mathrm{~mm}$ mesh size) receiving the overflowing water from the aquaria.

Total length (TL), dry weight $(W)$, elemental composition $(\mathrm{CHN})$ and proximate biochemical composition (total protein and lipid) of newly hatched larvae

Newly hatched larvae were taken in regular intervals (approximately monthly) for parallel determinations of 
total length (TL), dry weight $(W)$, elemental composition (contents of carbon, hydrogen and nitrogen; collectively $\mathrm{CHN}$ ) and proximate biochemical composition (total protein and lipid), which were measured with standard techniques (for recent description of details, see Urzúa and Anger 2011; Urzúa et al. 2012). The energy content was estimated from biochemical data (Winberg 1971), because conversions from CHN data (Salonen et al. 1976) tend to underestimate the energy content more strongly than conversions from biochemical composition (Anger 2001; Urzúa et al. 2012).

\section{Statistical analyses}

Statistical analyses were performed with standard methods (Sokal and Rohlf 1995) using the statistics software packages STATISTICA 8 (StatSoft) and Brodgar 2.6.6. All tests were run on the $95 \%$ confidence level $(P<0.05)$. Normality and homogeneity of variances were tested with Kolmogorov-Smirnov and Levene's tests, respectively. Data of seasonal variations in biomass and biochemical composition of newly hatched larvae were tested using a two-level nested ANOVA, with month as fixed factor and hatch (or female) as nested factor. Significant differences were analyzed with a multiple comparison test (StudentNewman-Keuls). Relationships between egg size and larval biomass at hatching were tested with regression analysis.

\section{Generalized additive models (GAM)}

We applied generalized additive models based on the R-mgcv function (Zuur et al. 2007) with various explanatory variables to determine, in a first step (GAM I), the influence of embryonic physiology (pre-hatching factors) on initial larval biomass. As a second step (GAM II), we evaluated relationships between larval quality and environmental parameters prevailing at the time of hatching (for more details, see Urzúa et al. 2012). Normality, outliers and collinearity were checked following Zuur et al. (2007).

\section{Effects of pre-hatching factors (GAM I)}

Data of initial egg biomass and mean temperature during the period of embryonic development were taken from Urzúa et al. (2012), and the effects of these factors on larval carbon content (used as a proxy for total organic matter) at hatching were tested with the following model:

$Y_{i}=\alpha+f_{1}\left(\mathrm{~EB}_{i}\right)+f_{2}\left(\mathrm{TE}_{i}\right)+\varepsilon_{i}$

with $Y=$ larval carbon $\left(\mu \mathrm{g}\right.$ larva $\left.^{-1}\right), \mathrm{EB}=$ initial egg biomass $\left(\mathrm{C}, \mu \mathrm{geg}^{-1}\right), \mathrm{TE}=$ mean temperature during the period of egg development $\left({ }^{\circ} \mathrm{C}\right), \alpha=$ intercept, $f_{1,2}=$ smoothing functions, $\varepsilon=$ error term, $i=$ observed data, $\sigma^{2}=$ variance, where $\varepsilon_{i} \sim n\left(0, \sigma^{2}\right)$.

Environmental conditions prevailing at the time of hatching (GAM II)

As explanatory variables, we included in this model the mean water temperature and phytoplankton carbon (as a proxy for food availability) measured through a fortnight period prior to the day of larval hatching (data from Wiltshire et al. 2010). The relationships between these environmental parameters and larval quality at hatching were explored with the equation:

$Y_{i}=\alpha+f_{1}\left(\mathrm{TH}_{i}\right)+f_{2}\left(\mathrm{~PB}_{i}\right)+\varepsilon_{i}$

with $Y=$ larval carbon $\left(\mu \mathrm{g} \operatorname{larva}^{-1}\right), \mathrm{TH}=$ mean temperature during a fortnight period prior to hatching $\left({ }^{\circ} \mathrm{C}\right)$, $\mathrm{PB}=$ mean phytoplankton biomass during a fortnight period prior to hatching $\left(\mathrm{mg} \mathrm{C} \mathrm{m}^{-3}\right)$; other parameters as above (Eq. 1).

\section{Results}

Seasonal variations in offspring size and female energy investment in egg production

Measurements of egg volume (Urzúa et al. 2012) revealed significant differences between seasons, with higher average values observed in winter than in summer $(44.3 \pm 3.26$ vs. $\left.34.5 \pm 1.66 \mathrm{~mm}^{3} \times 10^{-3} ; \quad F=242.76 ; \quad P<0.05\right)$. Corresponding with larger "winter eggs", larvae hatching in late winter and early spring were on average larger than those hatching in late spring and summer (total length, $2.80 \pm 0.12$ vs. $2.10 \pm 0.06 \mathrm{~mm} ; F=122.56 ; P<0.05$ ).

While the average number of eggs produced per female was significantly lower in winter than in summer $(1842 \pm 86$ vs. $2526 \pm 108 ; F=82.94 ; P<0.05)$, the female energy investment in egg production (calculated as number of egg multiplied by the energy content per egg) did not show significant seasonal differences $(1484 \pm 86$ vs. $1518 \pm 44 \mathrm{~J} ; F=1.22 ; P=0.18$ ).

Seasonal variations in larval dry weight $(W)$ and elemental composition (CHN) at hatching

Periodical samples of newly hatched larvae revealed that all values of biomass showed significant differences among months (Table 1). Maximal values were measured at the beginning of the larval hatching season in late winter (February-March), decreasing values during spring (AprilMay) and minimum values in summer (June-September) 
Table 1 Crangon crangon, newly hatched larvae

\begin{tabular}{|c|c|c|c|c|c|}
\hline Biomass parameters & Factor & SS & $d f$ & MS & $F$ \\
\hline \multirow[t]{4}{*}{$\mathrm{W}(\mu \mathrm{g})$} & Month & 2303.63 & 7 & 329.09 & $297.69 * * *$ \\
\hline & Hatch (month) & 209.89 & 24 & 8.75 & $7.91 *$ \\
\hline & Error & 106.13 & 96 & 1.11 & \\
\hline & Total & 2619.64 & 127 & & \\
\hline \multirow[t]{4}{*}{$\mathrm{C}(\mu \mathrm{g})$} & Month & 451.692 & 7 & 64.527 & $281.23 * * *$ \\
\hline & Hatch (month) & 42.972 & 24 & 1.791 & $7.80^{*}$ \\
\hline & Error & 22.027 & 96 & 0.229 & \\
\hline & Total & 516.691 & 127 & & \\
\hline \multirow[t]{4}{*}{$\mathrm{N}(\mu \mathrm{g})$} & Month & 38.3862 & 7 & 5.4837 & $299.67 * * *$ \\
\hline & Hatch (month) & 2.8055 & 24 & 0.1169 & $6.39 *$ \\
\hline & Error & 1.7568 & 96 & 0.0183 & \\
\hline & Total & 42.9484 & 127 & & \\
\hline \multirow[t]{4}{*}{$\mathrm{H}(\mu \mathrm{g})$} & Month & 14.0591 & 7 & 2.0084 & $363.88 * * *$ \\
\hline & Hatch (month) & 1.0340 & 24 & 0.0431 & $7.81 *$ \\
\hline & Error & 0.5299 & 96 & 0.0055 & \\
\hline & Total & 15.6230 & 127 & & \\
\hline \multirow[t]{4}{*}{ Lipid $(\mu \mathrm{g})$} & Month & 8.1994 & 7 & 1.1713 & $323.39 * * *$ \\
\hline & Hatch (month) & 0.6374 & 24 & 0.0266 & $7.33 *$ \\
\hline & Error & 0.5795 & 160 & 0.0036 & \\
\hline & Total & 9.4163 & 191 & & \\
\hline \multirow[t]{4}{*}{ Protein $(\mu \mathrm{g})$} & Month & 182.220 & 7 & 26.031 & $1011.6 * * *$ \\
\hline & Hatch (month) & 2.697 & 24 & 0.112 & $4.4 *$ \\
\hline & Error & 4.117 & 160 & 0.026 & \\
\hline & Total & 189.034 & 191 & & \\
\hline \multirow[t]{4}{*}{ E (J) } & Month & 0.63117 & 7 & 0.090167 & $388.65 * * *$ \\
\hline & Hatch (month) & 0.06995 & 24 & 0.002914 & $12.56^{*}$ \\
\hline & Error & 0.03722 & 160 & 0.000232 & \\
\hline & Total & 0.73834 & 191 & & \\
\hline \multirow[t]{4}{*}{$\mathrm{C}(\% \mathrm{~W})$} & Month & 56.5 & 7 & 8.1 & $10.8^{*}$ \\
\hline & Hatch (Month) & 109.5 & 24 & 4.6 & $6.1^{*}$ \\
\hline & Error & 72.1 & 96 & 0.8 & \\
\hline & Total & 238.1 & 127 & & \\
\hline \multirow[t]{4}{*}{$\mathrm{N}(\% \mathrm{~W})$} & Month & 34.69 & 7 & 4.96 & $36.88^{*}$ \\
\hline & Hatch (month) & 6.87 & 24 & 0.29 & $2.13 *$ \\
\hline & Error & 12.90 & 96 & 0.13 & \\
\hline & Total & 54.46 & 127 & & \\
\hline \multirow[t]{4}{*}{$\mathrm{H}(\% \mathrm{~W})$} & Month & 53.864 & 7 & 7.695 & $163.7 * *$ \\
\hline & Hatch (month) & 10.731 & 24 & 0.447 & $9.5^{*}$ \\
\hline & Error & 4.512 & 96 & 0.047 & \\
\hline & Total & 69.107 & 127 & & \\
\hline \multirow[t]{4}{*}{$\mathrm{C} / \mathrm{N}$ ratio } & Month & 0.970 & 7 & 0.139 & $14.8 *$ \\
\hline & Hatch (month) & 0.809 & 24 & 0.034 & $3.6^{*}$ \\
\hline & Error & 0.896 & 96 & 0.009 & \\
\hline & Total & 2.675 & 127 & & \\
\hline \multirow[t]{4}{*}{ Lipid (\% W) } & Month & 4.987 & 7 & 0.712 & $23.9 *$ \\
\hline & Hatch (month) & 5.124 & 24 & 0.214 & $7.2 *$ \\
\hline & Error & 4.765 & 160 & 0.030 & \\
\hline & Total & 14.877 & 191 & & \\
\hline
\end{tabular}


Table 1 continued

\begin{tabular}{|c|c|c|c|c|c|}
\hline Biomass parameters & Factor & SS & $d f$ & MS & $F$ \\
\hline \multirow[t]{4}{*}{ Protein $(\% \mathrm{~W})$} & Month & 32.8 & 7 & 4.7 & $37 *$ \\
\hline & Hatch (month) & 8.4 & 24 & 0.3 & $3 *$ \\
\hline & Error & 20.3 & 160 & 0.1 & \\
\hline & Total & 61.4 & 191 & & \\
\hline \multirow[t]{4}{*}{$\mathrm{E}\left(\mathrm{J}^{*} \mathrm{mg} \mathrm{W} \mathrm{W}^{-1}\right)$} & Month & 30.00 & 7 & 4.29 & $15.8^{*}$ \\
\hline & Hatch (month) & 31.23 & 24 & 1.30 & $4.81^{*}$ \\
\hline & Error & 43.02 & 160 & 0.27 & \\
\hline & Total & 104.25 & 191 & & \\
\hline
\end{tabular}

Two-level nested ANOVA evaluating differences in dry weight, elemental composition and proximate biochemical composition among months and hatches nested within months; interaction between these factors; biomass parameters: $(W)$ dry weight, $(C)$ contents of carbon, $(N)$ nitrogen, $(H)$ hydrogen, $\mathrm{C} / \mathrm{N}$ ratio, lipid, protein and $(E)$ energy; significant differences marked with asterisks $(* P<0.05 ; * * P<0.01 ; * * * P<0.001)$

(Figs. 1, 3). Hence, larvae hatching during winter were heavier than those hatching in summer (Fig. 1a). Consistent with higher dry weight, "winter larvae" showed also higher contents of CHN per individual (Fig. 1b-d). Their average biomass reached twice the values recorded in "summer larvae" (11 vs. $6 \mu \mathrm{g} \mathrm{C} ; 3$ vs. $1.5 \mu \mathrm{g} \mathrm{N} ; 1.8$ vs. $1 \mu \mathrm{g} \mathrm{H}$; cf. February vs. July) (Fig. 1).

While all absolute values of biomass per larva showed highly significant differences among months (all $P<0.001)$, values expressed in percent of dry weight showed only marginally significant differences $(P<0.05)$ (Table 1). For example, carbon and nitrogen (expressed in
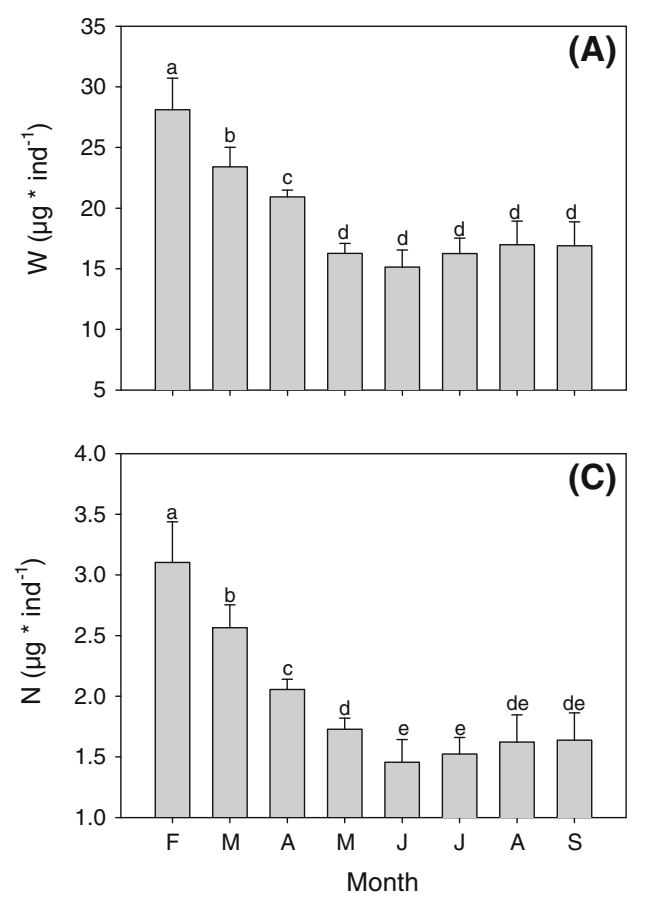

Fig. 1 Crangon crangon, newly hatched larvae. Seasonal variations in dry weight $(W)$ and elemental composition $(\mathrm{CHN})$ : a dry weight, b carbon, $\mathbf{c}$ nitrogen and $\mathbf{d}$ hydrogen (all expressed in $\mu \mathrm{g}^{-1} \mathrm{~d}^{-1}$ );
$\% \mathrm{~W})$ remained relatively stable at average levels of about 37 and $10 \%$, respectively (Fig. 2).

Seasonal variations in the proximate biochemical composition of larval biomass

The biochemical composition (total lipid and protein per larva) and energy content ( $\mathrm{J}$ per larva, estimated from biochemical data) showed similar patterns as dry weight and elemental composition (Fig. 3). Again, a maximum level was found in February-March, with average values of about $1.3 \mu \mathrm{g}$ lipid, $8 \mu \mathrm{g}$ protein and $0.7 \mathrm{~J}$ per larva.
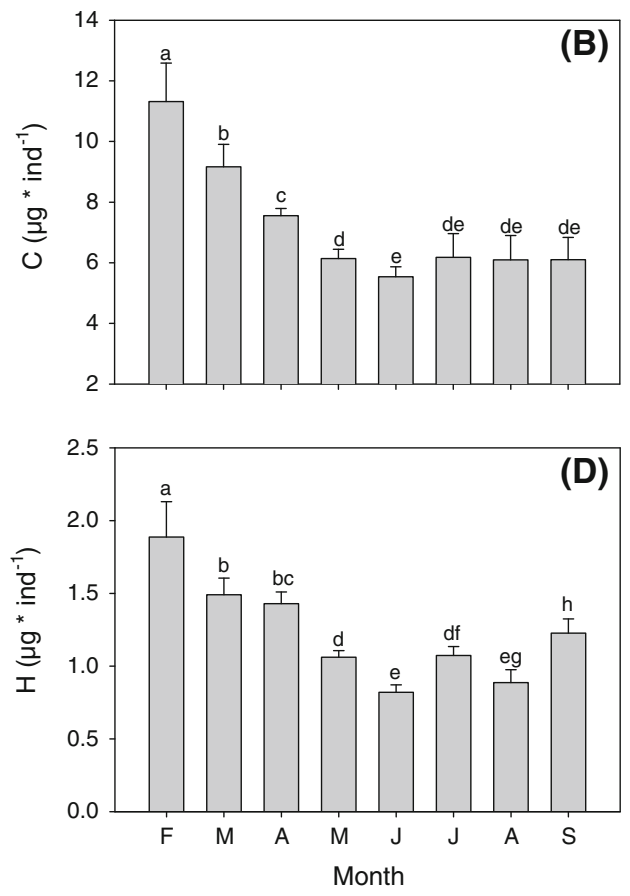

mean values \pm SD. Different lower case letters indicate significant differences among months (after SNK test) 

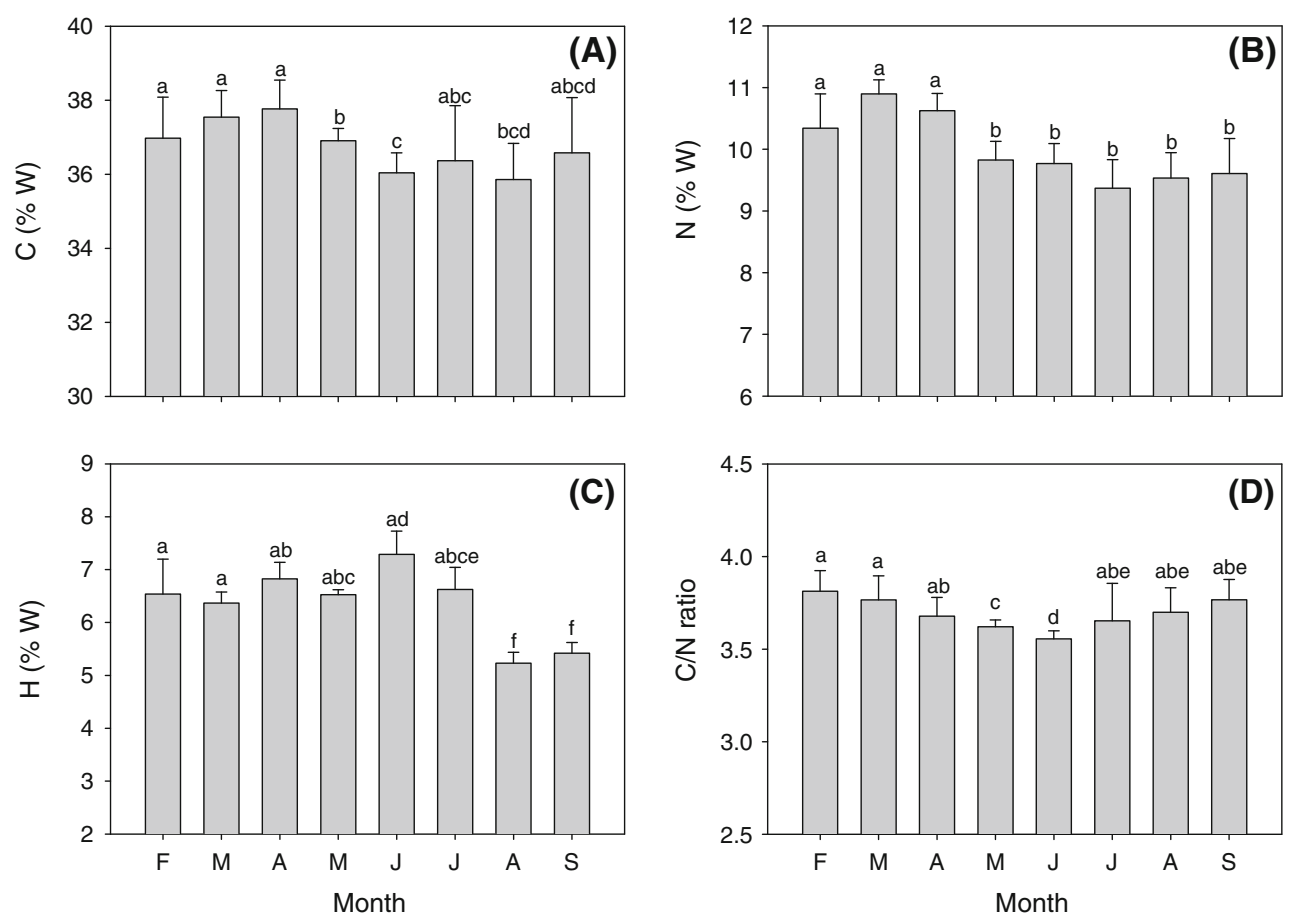

Fig. 2 Crangon crangon, newly hatched larvae. Seasonal variations in elemental composition: a carbon, $\mathbf{b}$ nitrogen and $\mathbf{c}$ hydrogen (all expressed in $\%$ of $\mathrm{W})$; $\mathbf{d} \mathrm{C} / \mathrm{N}$ ratio; mean values $\pm \mathrm{SD}$. Different

lower case letters indicate significant differences among months (after SNK test)

Decreasing levels were measured from April to June, with minimum values about $0.7 \mu \mathrm{g}$ lipid, $5 \mu \mathrm{g}$ protein and $0.45 \mathrm{~J}$. A slight increase occurred subsequently between July and September, reaching values of about $0.8 \mu \mathrm{g}$ lipid, $6 \mu \mathrm{g}$ protein and $0.5 \mathrm{~J}$ (Fig. 3). All values of lipid, protein and energy content per larva differed significantly among months (all $P<0.001)$ (Table 1).

Compared to the absolute biomass values, the relative biochemical composition and energy content (expressed in $\%$ of $\mathrm{W}$ or $\mathrm{J} \mathrm{mg} \mathrm{W}^{-1}$, respectively) showed only marginally significant seasonal variations throughout the reproductive period $(P<0.05)$ (Table 1$)$, with average values of about $5.7 \%$ lipid, $46 \%$ protein and $18.5 \mathrm{~J} \mathrm{mg} \mathrm{W}^{-1}$ (Fig. 3).

\section{Relationships between egg size and elemental composition of newly hatched larvae}

The elemental composition (CHN) and energy content ( $E$, estimated from biochemical data) of newly hatched larvae (values in $\mu \mathrm{g}$ or $\mathrm{J}$ per individual, respectively) were positively correlated with egg size $\left(r^{2}=0.71,0.73,0.68\right.$ and 0.75 for $\mathrm{C}, \mathrm{N}, \mathrm{H}$ and $E$, respectively; all $P<0.001$, Fig. 4). Seasonal variations in egg size are thus propagated to larval biomass at hatching, so that larvae hatching from larger "winter eggs" showed higher CHN and energy values than those hatching from smaller "summer eggs".

\section{Effects of pre-hatching factors}

According to generalized additive models (GAM) of multiple explanatory variables, a combination of key factors related to embryonic physiology exerted significant effects on the carbon content of newly hatched larvae. Based on the smoothing function of the GAM I model, the carbon content at hatching showed a highly significant positive relationship with initial egg biomass (data from Urzúa et al. 2012) and a negative relation with the average incubation temperature during the period of embryonic development (Fig. 5a, b; Table 2). About $60 \%$ of the variation in the carbon content per larva can be explained by effects of seasonal variations in embryonic carbon, while the average incubation temperature contributed $35 \%$ to the variation in the carbon content of newly hatched larvae (Fig. 5a, b).

Effects of environmental conditions prevailing at the time of hatching

The temperature $(\mathrm{TH})$ and phytoplankton biomass $(\mathrm{PB})$ prevailing at the time of hatching are significantly linked with initial larval quality (measured as $\mathrm{C}$ content). An additive model of multiple explanatory variables indicated that larval $\mathrm{C}$ showed highly significant negative correlations with both TH $\left(r^{2}=0.57 ; P<0.001\right)$ and $\mathrm{PB}$ $\left(r^{2}=0.39 ; P<0.001\right)$ measured at the time of hatching 

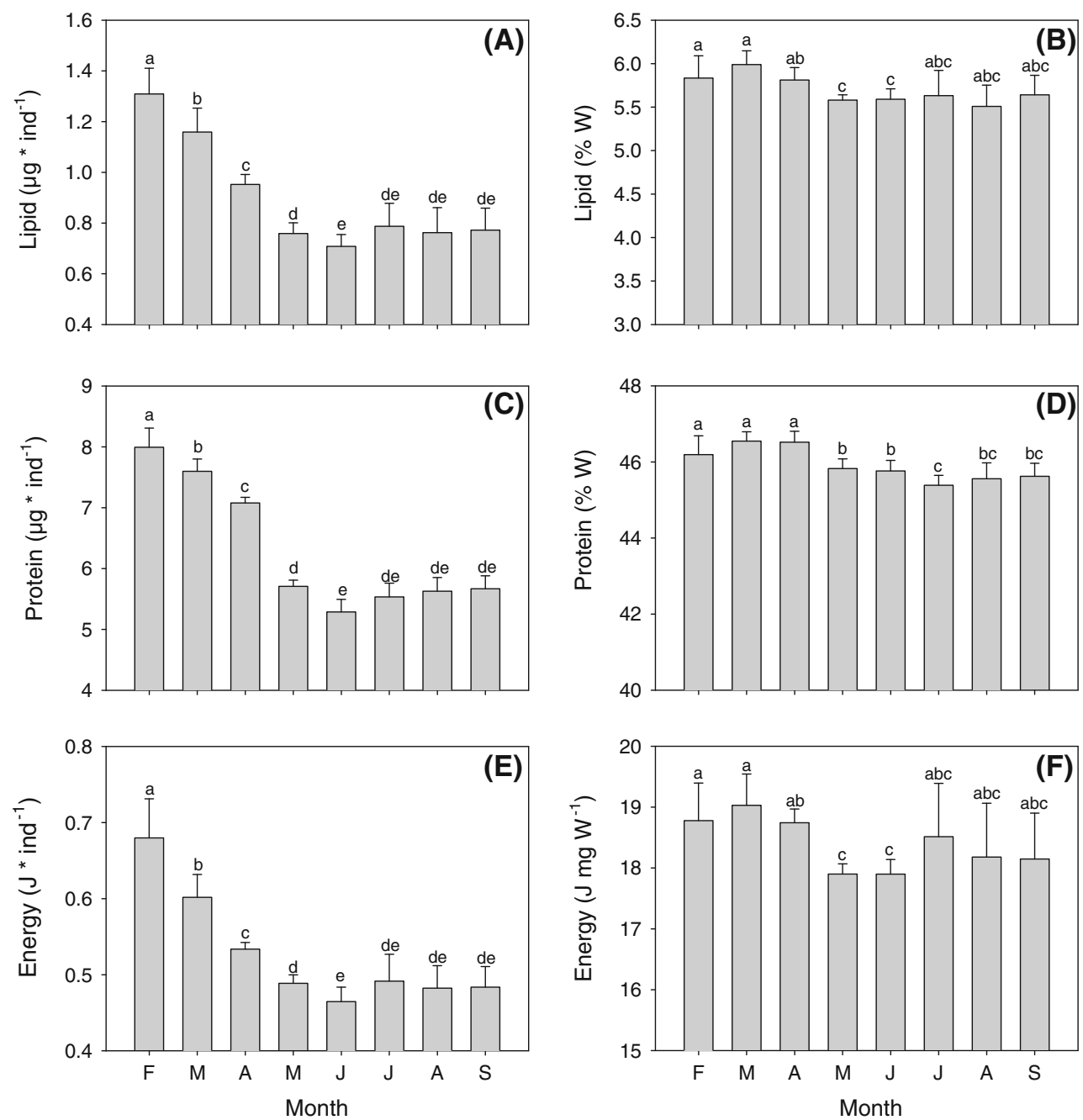

Fig. 3 Crangon crangon, newly hatched larvae. Seasonal variations in proximate biochemical composition: a, b lipid, expressed in $\mu \mathrm{g}^{-1} \mathrm{in}^{-1}$ and $\%$ of $W$, respectively; c, d protein, expressed in $\mu \mathrm{g}$ ind $^{-1}$ and $\%$ of $W$, respectively; e, $\mathbf{f}$ energy content (estimated

(Table 2). According to the GAM II model, the smoothing function for larval quality showed a maximum level in winter (environmental conditions at the time of hatching: ca. $5{ }^{\circ} \mathrm{C}$ and $27 \mathrm{mg} \mathrm{C} \mathrm{m}^{-3} \cdot 10$; $\mathrm{TH}$ and $\mathrm{PB}$, respectively), decreased gradually thereafter, reached a minimum in spring (ca. $10{ }^{\circ} \mathrm{C}$ and $38 \mathrm{mg} \mathrm{C} \mathrm{m}^{-3} \cdot 10$ ) and increased subsequently again in late summer (ca. $17{ }^{\circ} \mathrm{C}$ and $62 \mathrm{mg} \mathrm{C}$ $\left.\mathrm{m}^{-3} \cdot 10\right)$ (Fig. 5c, d).

\section{Discussion}

In marine invertebrates with complex life cycles, the different life-history stages are closely linked to each other (Allen and Marshall 2010; Harrison et al. 2011). In the early stages of the life cycle of $C$. crangon, our results indicate that seasonal variations in egg size are translated

from biochemical data), expressed in $\mathrm{J}_{\text {ind }}{ }^{-1}$ and $\mathrm{J} \mathrm{mg} \mathrm{W}^{-1}$, respectively; mean values \pm SD. Different lower case letters indicate significant differences among months (after SNK test)

to variations in larval biomass. We demonstrate here that larvae hatching from larger "winter eggs" show higher absolute values of elemental $(\mathrm{CHN})$ and biochemical constituents (lipid, protein) than larvae hatching from smaller "summer eggs".

In crustaceans, larval traits at hatching are related to key variables associated with embryonic development (Giménez and Anger 2001; Webb et al. 2007). For example, the average egg incubation temperature exerts significant effects on the development time and bioenergetics of the embryo and influences the initial larval biomass at hatching (Paschke 1998; Fischer et al. 2009). In C crangon, the initial larval biomass was negatively correlated with the incubation temperature during egg development. Compared to larvae hatching from eggs that had been incubated at cold winter temperatures, "summer larvae" showed lower values of biomass. While egg development is 
Fig. 4 Crangon crangon, newly hatched larvae. Linear regression model evaluating relationship between egg size (volume) and elemental composition of newly hatched larvae: $y=\mathbf{a}$ carbon, b nitrogen, $\mathbf{c}$ hydrogen and d energy content (all expressed in values per larva); $a=$ intercept, $b=$ slope; $r^{2}=$ determination coefficient; $P=$ significance level; in all cases $n=128$
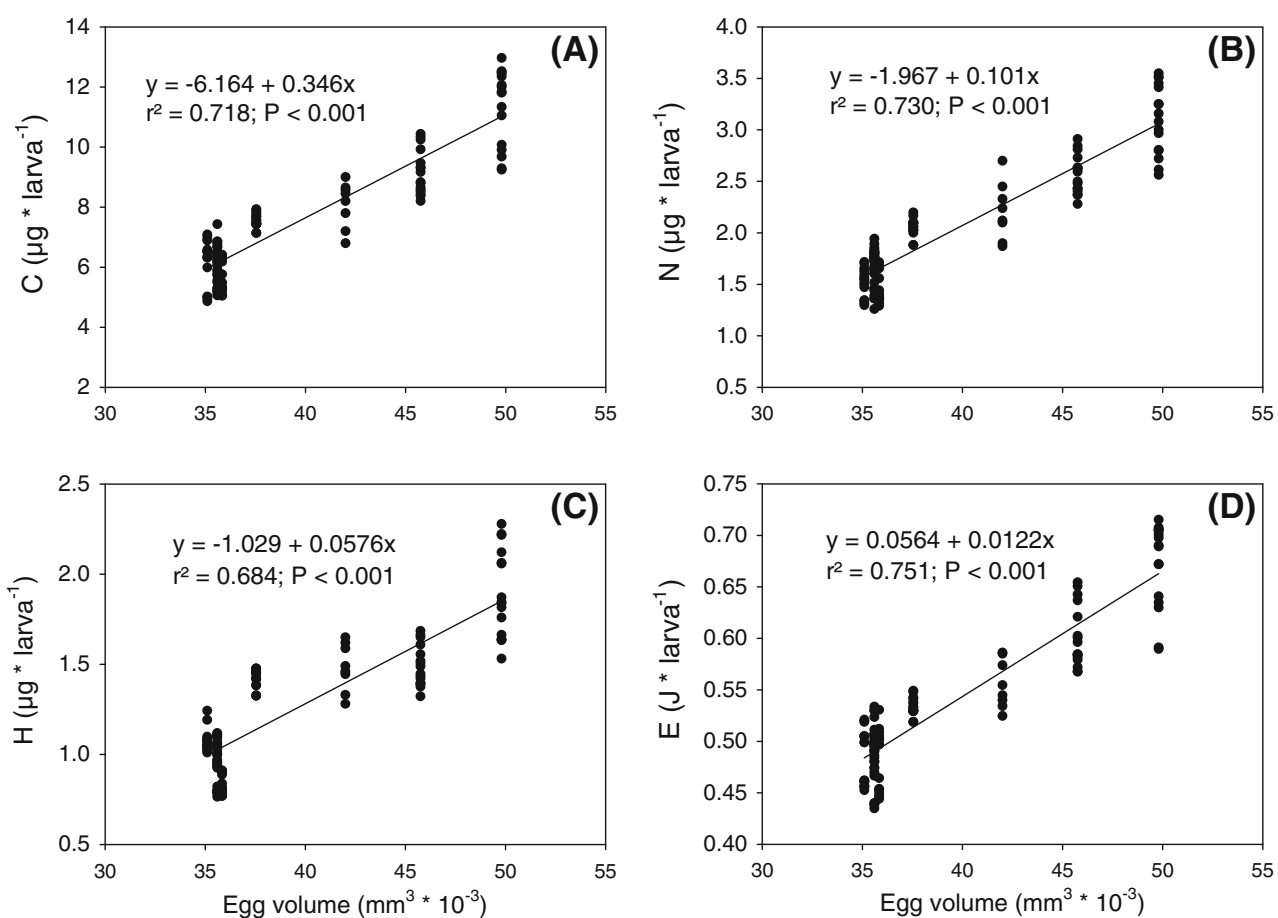

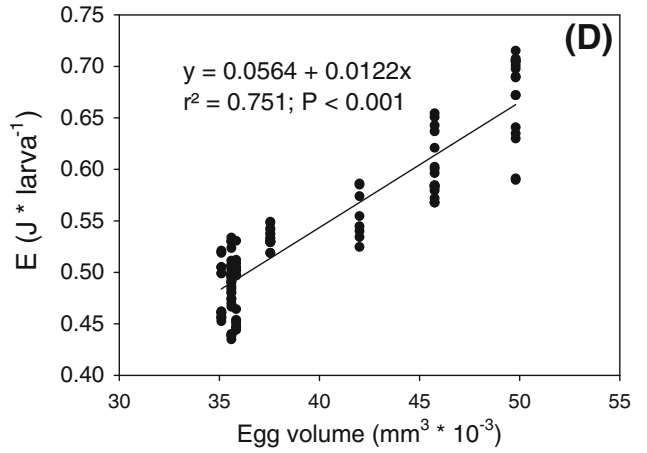

accelerated at higher temperatures, this may be at the cost of changes in metabolic efficiency (Kunisch and Anger 1984), leading to a reduction in initial larval biomass. This has been shown in various caridean shrimp species, for example, Betaeus emarginatus and Pandalus borealis (Wehrtmann and Lopez 2003; Brillon et al. 2005).

In order to evaluate the adaptive significance of intraspecific variation in egg size, we need to understand how differential traits may be carried over to later life-history stages. Most likely, an enhancement of larval biomass at hatching should improve larval survival under suboptimal food conditions. This may be influenced by genetic or maternal factors that are involved in the determination of larval quality (Palacios et al. 1998; Meidel et al. 1999).

In planktonic organisms living in environments with seasonal variations in productivity (food availability), parental organisms may assess the nutritional conditions that their offspring will likely encounter and adjust the energy investment per offspring accordingly (Fischer et al. 2011). According to the relationship between environmental conditions prevailing at hatching and larval biomass observed in our study, the smoothing function of GAM showed a maximum level in larval biomass during winter, a minimum in the late spring and another increase in late summer. High larval carbon content during late winter may improve the tolerance of fasting, when poor nutritional conditions coincide with prolonged duration of larval development at cold temperatures (Criales and Anger 1986; Paschke et al. 2004; Daewel et al. 2011). Hence, the production of larger "winter larvae" seems to be an adaptive reproductive trait of $C$. crangon, allowing for an extension of the period of reproduction (Siegel et al. 2008; Urzúa et al. 2012), which is in most other decapod crustaceans in temperate regions restricted to late spring and summer (Anger 2001). At higher temperatures and planktonic food concentration, during late spring and summer (Wiltshire et al. 2008), smaller shrimp larvae hatch in the southern North Sea. This match between favorable conditions of food availability and high temperatures with larval peak abundance during spring-summer (Wehrtmann 1989) allows the larvae to exploit rich food resources and reach fast rates of growth and development (Temming and Damm 2002). In this way, our study confirms the hypotheses proposed by Paschke et al. (2004) and provides a chemical basis explaining the previously observed seasonal patterns in larval starvation resistance. Similar seasonal variations in offspring quality and environmental conditions prevailing at hatching have also been described in other aquatic crustacean species, for example in porcelain crab (Gebauer et al. 2010), marine copepods (Acheampong et al. 2011) and limnic cladocerans (Boersma 1997).

While the production of large larvae in winter is probably related mainly to low food availability, larger size could also play a role as a protection from predators (Morgan 1995). Predation is a major cause of larval mortality in C. crangon (e.g. Henderson et al. 2006), with various fish species being well-known predators (Tiews 1978). As large "winter larvae" show a prolonged planktonic development time, they are also exposed to a higher risk of predation. By contrast, smaller "summer larvae" 
Fig. 5 Crangon crangon, newly hatched larvae.

Smoothing function

$(S)$ obtained by generalized additive model (GAM) for larval carbon content $(\mathrm{C}$, $\mu$ larva $^{-1}$ ) exploring the effects of pre-hatching factors [a initial egg biomass and b incubation temperature] and the environmental conditions prevailing at the time of hatching [c temperature and d phytoplankton biomass]. These plots allow evaluating the relationships between explanatory variables ( $x$-axis) and adjusted residuals of dependent variable (carbon, $y$ axis). Solid line estimated smoothing function; dotted lines $95 \%$ confidence intervals. Total variance is quantified by values of $r^{2}$, the significance of the smoothing function by values of $F$ and $P$; dots represent mean values, in all cases $n=128$. For statistical model and parameters, see Table 2
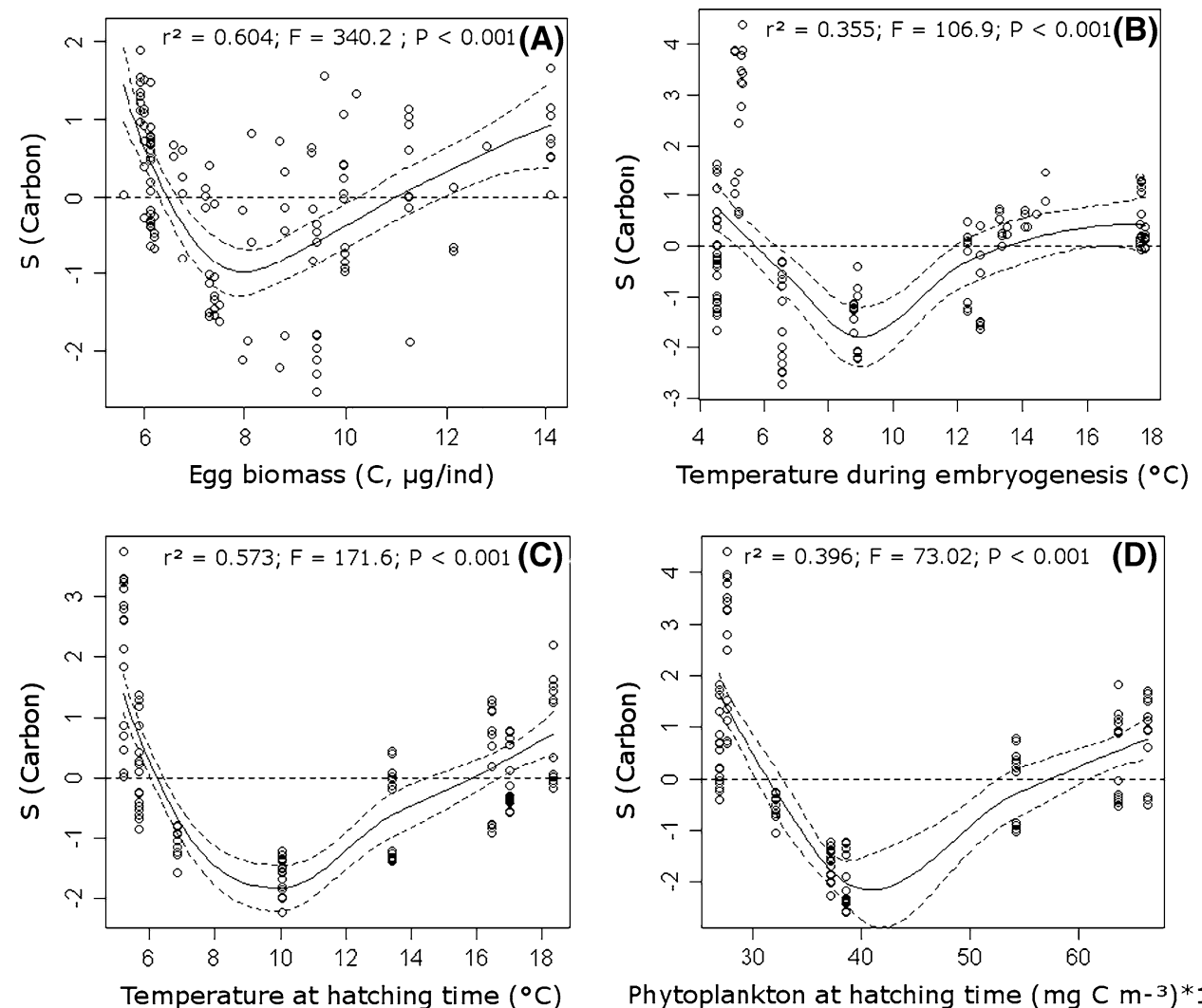

Phytoplankton at hatching time $\left(\mathrm{mg} \mathrm{C} \mathrm{m}^{-3}\right) * 10$

Table 2 Crangon crangon, newly hatched larvae

\begin{tabular}{lcccc}
\hline Parametric coefficients & Estimate & SE & $t$ value & $r^{2}$ \\
\hline Effects of pre-hatching factors & & & & \\
$\quad$ Intercept & -3.332 & 0.58 & -5.721 & - \\
$\quad$ Initial egg biomass & 0.402 & 0.021 & 17.42 & 0.60 \\
Temperature during embryogenesis & -0.278 & 0.026 & -10.34 & 0.35 \\
Environmental conditions & & & $<0.001$ \\
Intercept & 10.56 & 0.36 & 29.31 & - \\
Temperature prevailing at hatching time & -0.303 & 0.023 & -13.1 & 0.57 \\
Phytoplankton prevailing at hatching time & -0.081 & 0.009 & -8.545 & $0.39<0.001$ \\
\hline
\end{tabular}

Additive model of various explanatory variables evaluating the effects of pre-hatching factors and environmental conditions prevailing at the time of hatching on larval condition; evaluated parameters, estimate, SE, $t$ values, coefficients of determination $\left(r^{2}\right)$, significance level $(P$ value $)$

show faster rates of development and growth (Linck 1995; Criales and Anger 1986), which reduces the time of exposure to predation and other potential risks in the plankton, enhancing the chance of successful recruitment (Morgan 1995).

Crangon crangon produces fewer but larger "winter eggs" and a higher number of smaller "summer eggs" (Urzúa et al. 2012). In this context, the female energy investment in egg production did not show significant differences between winter and summer. In $C$. crangon, as well as other decapod crustaceans, total energy investment in embryo production is influenced by maternal traits such as female size and abdominal space available for egg incubation (Ouellet and Plante 2004; Moland et al. 2010).

The reproductive traits of $C$. crangon may vary over latitudinal gradients within the large climatic range of distribution of this species (Tiews 1970; Campos and van der Veer 2008). In populations at lower latitudes (e.g. the west coast of Portugal, southwestern Europe), reproduction takes place only from late winter to early summer, with a main spawning and breeding season during spring (Marchand 1981; Viegas et al. 2012). The offspring there is smaller, and no seasonal variations in egg weight have been observed (Viegas et al. 2012). In the warmer and 
seasonally less variable Mediterranean Sea, the brown shrimp shows a shorter breeding season, comprising only the coldest months from November to April (Gelin et al. 2000). In conclusion, strong seasonality in plankton production of temperate regions, such as the southern North Sea, may represent a selection factor favouring an evolution of seasonal variability in larval biomass. We suggest that this reproductive trait allows the brown shrimp to extend its reproductive period.

Besides seasonal, also interannual variability has been observed in the biomass of crustacean offspring (e.g. Shirley and Shirley 1989; Giménez 2010; Urzúa et al. 2012). In future investigations, it would thus be interesting, especially in the context of climate change, to further consider variability among year classes of eggs and larvae and their relationships with variations in environmental factors.

Our study shows that seasonal variations in egg biomass of $C$. crangon are propagated to similar patterns of variation in larval biomass at hatching, indicating "carry-over effects" from the embryonic to the larval phase. Future studies of temperate species including $C$. crangon should thus investigate whether seasonal variations in larval biomass are propagated also further into the juvenile phase (see Giménez 2006, 2010; Pechenik 2006). In brown shrimp, comparative studies of the influence of temperature and food conditions on development time, survival and growth of both "winter larvae" and "summer larvae" may reveal implications for the condition of benthic juveniles and adults and thus for the stability and production of an important marine fishery resource.

Acknowledgments We thank the crews of R. V. "Uthörn" for capture and transporting live shrimps to Helgoland; Uwe Nettelmann helped in the maintenance of the animals; Julia Haafke made elemental analyses. We also thank two anonymous reviewers for constructive criticism and helpful suggestions. AU was financially supported by the Deutscher Akademischer Austauschdienst (DAAD, Bonn, Germany) and the Comisión Nacional de Ciencia y Tecnología, CONICYT (Santiago de Chile) funding this study as a part of his doctoral dissertation. The experiments comply with animal manipulation laws in Germany.

\section{References}

Acheampong E, Campbell RW, Diekmann ABS, John MA (2011) Food availability effects on reproductive strategy: the case of Acartia tonsa (Copepoda: Calanoida). Mar Ecol Prog Ser 428:151-159

Allen RM, Marshall DJ (2010) The larval legacy: cascading effects of recruit phenotype on post-recruitment interactions. Oikos 119:1977-1983

Anger K (2001) The biology of decapod crustacean larvae. Crustacean issues, vol 14. Balkema, Lisse

Anger K (2006) Contributions of larval biology to crustacean research: a review. Invertebr Reprod Dev 49:175-205
Anger K, Thatje S, Lovrich G, Calcagno J (2003) Larval and early juvenile development of Paralomis granulosa reared at different temperatures: tolerance of cold and food limitation in a lithotid crab from high latitudes. Mar Ecol Prog Ser 253:243-251

Boddeke R (1982) The occurence of winter and summer eggs in the brown shrimp (Crangon crangon) and the pattern of recruitment. Neth J Sea Res 16:151-162

Boersma M (1997) Offspring size in Daphnia: does it pay to be overweight? Hydrobiologia 360:79-88

Brillon S, Lambert Y, Dodson J (2005) Egg survival, embryonic development, and larval characteristics of northern shrimp (Pandalus borealis) females subject to different temperature and feeding conditions. Mar Biol 147:895-911

Calado R, Dionisio G, Dinis MT (2007) Starvation resistance of early zoeal stages of marine ornamental shrimps Lysmata spp. (Decapoda: Hippolytidae) from different habitats. J Exp Mar Biol Ecol 351:226-233

Campos J, van der Veer H (2008) Autoecology of Crangon crangon (L.) with an emphasis on latitudinal trends. Ocean Mar Biol Annu Rev 46:65-105

Campos J, van der Veer H, Freitas V, Kooijman S (2009) Contribution of different generations of the brown shrimp Crangon crangon (L.) in the Dutch Wadden Sea to commercial fisheries: a dynamic energy budget approach. J Sea Res 62:106-113

Criales MM, Anger K (1986) Experimental studies on the larval development of the shrimps Crangon crangon and C. allmanni. Helgoländer Meeresunters 40:241-265

Daewel U, Schrum C, Temming A (2011) Towards a more complete understanding of the life cycle of brown shrimp (Crangon crangon): modelling passive larvae and juvenile transport in combination with physically forced vertical juvenile migration Fish. Oceanogr 20:479-496

Fernandez M, Calderon R, Cifuentes M, Pappalardo P (2006) Brooding behaviour and cost of brooding in small body size brachyuran crabs. Mar Ecol Prog Ser 309:213-220

Fischer S, Thatje S, Graeve M, Paschke K, Kattner G (2009) Bioenergetics of early life-history stages of the brachyuran crab Cancer setosus in response to changes in temperature. J Exp Mar Biol Ecol 374:160-166

Fischer B, Taborsky B, Kokko H (2011) How to balance the offspring quality-quantity tradeoff when environmental cues are unreliable. Oikos 120:258-270

Gebauer P, Paschke K, Anger K (2010) Seasonal variation in the nutritional vulnerability of first-stage larval porcelain crab, Petrolisthes laevigatus (Anomura: Porcellanidae) in southern Chile. J Exp Mar Biol Ecol 386:103-112

Gelin A, Crivelli AJ, Rosecchi AJ, Kerambrun P (2000) Is the brown shrimp Crangon crangon (L.) population of the Vaccarès lagoon (Camargue, France, Rhône delta) an annual population? C R Acad Sci III 323:741-748

Giménez L (2006) Phenotypic links in complex life cycles: conclusions from studies with decapod crustaceans. Integr Comp Biol 46:615-622

Giménez L (2010) Relationships between habitat conditions, larval traits, and juvenile performance in a marine invertebrate. Ecology 91:1401-1413

Giménez L, Anger K (2001) Relationships among salinity, egg size, embryonic development, and larval biomass in the estuarine crab Chasmagnathus granulata Dana, 1851. J Exp Mar Biol Ecol 260:241-257

Grosberg RK, Levitan DR (1992) For adults only? Supply-side ecology and the history of larval biology. Trends Ecol Evol 7:130-133

Harrison XA, Blount JD, Inger R, Norris DR, Bearhop S (2011) Carry-over effects as drivers of fitness differences in animals. J Anim Ecol 80:4-18 
Henderson PA, Seaby RM, Somes JR (2006) A 25-year study of climatic and density-dependent population regulation of common shrimp Crangon crangon (Crustacea: Caridea) in the Bristol Channel. J Mar Biol Assoc UK 86:287-298

Hufnagl M, Temming A (2011) Growth in the brown shrimp Crangon crangon. II. Meta-analysis and modeling. Mar Ecol Pro Ser 435:155-172

ICES (2010) Report of the working group on Crangon fisheries and life history (WGCRAN). ICES CM 2010/SSGEF, vol 17

Jaeckle WB (1995) Variation in the size, energy content, and biochemical composition of invertebrate eggs: correlates to the mode of larval development. In: McEdward L (ed) Ecology of marine invertebrate larvae. CRC Press, Boca Raton, pp 49-77

Kunisch M, Anger K (1984) Variation in development and growth rates of larval and juvenile spider crabs Hyas araneus reared in the laboratory. Mar Ecol Prog Ser 15:293-301

Linck BM (1995) Einfluß von Temperatur und Salzgehalt auf die Larven der Nordseegarnele Crangon crangon. Master thesis, University of Oldenburg, Germany

Marchand J (1981) Observations on the ecology of Crangon crangon (Linne) and Palaemon longirostris H. Milne Edwards (Crustacea, Decapoda, Natantia): inner part of the Loire estuary (France). Vie Milieu 31:83-92

Marshall DJ, Keough MJ (2006) Complex life cycles and offspring provisioning in marine invertebrates. Integr Comp Biol 46:643-651

McCormick M, Hoey A (2004) Larval growth history determines juvenile growth and survival in a tropical marine fish. Oikos 106:225-242

Meidel SK, Scheibling RE, Metaxas A (1999) Relative importance of parental and larval nutrition on larval development and metamorphosis of the sea urchin Strongylocentrotus droebachiensis. J Exp Mar Biol Ecol 240:161-178

Moland E, Moland OE, Stenseth NC (2010) Maternal influences on offspring size variation and viability in wild European lobster Homarus gammarus. Mar Ecol Prog Ser 400:165-173

Morgan SG (1995) Life and death in the plankton: larval mortality and adaptation. In: McEdward L (ed) Ecology of Marine Invertebrate Larvae. CRC Press, Boca Raton, pp 279-321

Ouellet P, Plante F (2004) An investigation of the sources of variability in American lobster (Homarus americanus) eggs and larvae: female size and reproductive status, and interannual and interpopulation comparisons. J Crustac Biol 24:481-495

Palacios E, Ibarra AM, Ramirez JL, Portillo G, Racotta IS (1998) Biochemical composition of eggs and nauplii in White Pacific Shrimp, Penaeus vannamei (Boone), in relation to the physiological condition of spawners in a commercial hatchery. Aquacult Res 29:183-189

Pan M, Pierce G, Cunningham C, Hay S (2011) Spatiotemporal coupling/decoupling of planktonic larvae and benthic settlement in decapods in the Scottish east coast. Mar Biol 158:31-46

Paschke K (1998) Untersuchungen zum Energiestoffwechsel während der Embryonalentwicklung der Nordsee-Garnele Crangon crangon (Linnaeus 1758) (Decapoda: Caridea). Dissertation, University of Hamburg, Germany

Paschke KA, Gebauer P, Buchholz F, Anger K (2004) Seasonal variation in starvation resistance of early larval North Sea shrimp Crangon crangon (Decapoda: Crangonidae). Mar Ecol Prog Ser 279:183-191

Pechenik JA (2006) Larval experience and latent effects-metamorphosis is not a new beginning. Integr Comp Biol 46:323-333

Pihl L, Rosenberg R (1984) Food selection and consumption of the shrimp Crangon crangon in some shallow marine areas in western Sweden. Mar Ecol Prog Ser 15:159-168
Podolsky RD, Moran AL (2006) Integrating function across marine life cycles. Integr Comp Biol 46:577-586

Racotta IS, Palacios E, Ibarra AM (2003) Shrimp larval quality in relation to broodstock condition. Aquaculture 227:107-130

Roughgarden J, Gaines S, Possingham H (1988) Recruitment dynamics in complex life cycles. Science 241:1460-1466

Salonen K, Sarvala J, Hakala I, Viljamen ML (1976) The relation of energy and organic carbon in aquatic invertebrates. Limnol Oceanogr 21:724-730

Shirley SM, Shirley TC (1989) Interannual variability in density, timing and survival of Alaskan red king crab Paralithodes camtschatica larvae. Mar Ecol Prog Ser 54:51-59

Siegel V, Damm U, Neudecker T (2008) Sex-ratio, seasonality and long-term variation in maturation and spawning of the brown shrimp Crangon crangon (L.) in the German Bight (North Sea). Helgol Mar Res 62:339-349

Sokal R, Rohlf J (1995) Biometry, 3rd edn. W.H. Freeman, New York Temming A, Damm U (2002) Life cycle of Crangon crangon in the North Sea: a simulation of the timing of recruitment as a function of the seasonal temperature signal. Fish Oceanogr 11:45-58

Tiews K (1970) Synopsis of biological data on the common shrimp Crangon crangon (Linnaeus, 1758). FAO Fish Rep 57:11671224

Tiews K (1978) The predator-prey relationship between fish populations and the stock of brown shrimp (Crangon crangon L.) in German coastal waters. Rapp P-v Reun Cons int Explor Mer 172:250-258

Urzúa Á, Anger K (2011) Larval biomass and chemical composition at hatching in two geographically isolated clades of the shrimp Macrobrachium amazonicum: intra-or interspecific variation? Invertebr Reprod Dev 55:236-246

Urzúa Á, Paschke K, Gebauer P, Anger K (2012) Seasonal and interannual variations in size, biomass and chemical composition of the eggs of North Sea shrimp, Crangon crangon (Decapoda: Caridea). Mar Biol 159:583-599

Viegas I, Marques S, Bessa F, Primo A, Martinho F, Azeiteiro U, Pardal MÂ (2012) Life history strategy of a southern European population of brown shrimp (Crangon crangon L.): evidence for latitudinal changes in growth phenology and population dynamics. Mar Biol 159:33-43

Wear RG (1974) Incubation in British Decapod Crustacea, and the effects of temperature on the rate and success of embryonic development. J Mar Biol Assoc UK 54:745-762

Webb JB, Eckert GL, Shirley TC, Tamone SL (2007) Changes in embryonic development and hatching in Chionoecetes opilio (Snow Crab) with variation in incubation temperature. Biol Bull 213:67-75

Wehrtmann IS (1989) Seasonal occurrence and abundance of caridean shrimp larvae at Helgoland, German Bight. Helgol Mar Res 43:87-112

Wehrtmann IS, Lopez GA (2003) Effects of temperature on the embryonic development and hatchling size of Betaeus emarginatus (Decapoda: Caridea: Alpheidae). J Nat Hist 37:2165-2178

Wiltshire KH, Malzahn AM, Greve W, Wirtz K, Janisch S, Mangelsdorf P, Manly B, Boersma M (2008) Resilience of North Sea phytoplankton spring bloom dynamics: an analysis of long-term data at Helgoland Roads. Limnol and Ocean 53:1294-1302

Wiltshire K, Kraberg A, Bartsch I, Boersma M, Franke H, Freund J, Gebühr C, Gerdts G, Stockmann K, Wichels A (2010) Helgoland roads, North Sea: 45 years of change. Estuar Coasts 33:295-310

Winberg GG (1971) Methods for the estimation of production of aquatic animals. Academic Press, London

Zuur AF, Leno EN, Graham SM (2007) Analysing ecological data (statistics for biology and health). Springer, New York 